\title{
Effect of parabolic solar energy collectors for water distillation
}

\begin{abstract}
This research article briefly summarizes the augmentation of condensate output using concentrators. This study compares a single-slope solar still, a compound conical concentrator (CCC) solar still, and a compound parabolic concentrator-tubular solar still (CPC-TSS). The effect of miniaturization of the absorber (increase in the concentration factor) and some modifications in the solar still assembly show a remarkable increase in output. The measured daily yield rate per square meter of absorber area of the single slope solar still, CCC solar still, and CPC-TSS is 2,100, 18,000, and 6,100 ml, respectively. It was found that the $\mathrm{CCC}$ solar still provides the maximum yield.
\end{abstract}

Keyword: Compound conical concentrator; Compound parabolic concentrator; Desalination; Solar still 